\title{
Australian Journal of

\section{Evaluation of the honey and pollen yield of Melipona interrupta bee colonies in the Amazon region}

\author{
Adcleia P. PIRES* ${ }^{1}$, Aline PACHECO ${ }^{1}$, Lucieta G. MARTORANO ${ }^{2}$, Jonival M. NETO ${ }^{4}$, José Reinaldo da Silva \\ Cabral de MORAES ${ }^{3}$, Lucas Eduardo de Oliveira APARECIDO ${ }^{3}$
}

\author{
${ }^{1}$ Federal University of Western Pará (UFOPA), Santarém-PA, Brazil \\ ${ }^{2}$ Brazilian Agricultural Research Agency (Embrapa Amazônia Oriental/NAPT do Médio Amazonas), Santarém, PA, Brazil \\ ${ }^{3}$ State University of São Paulo (UNESP), Jaboticabal, SP, Brazil \\ ${ }^{4}$ The University of Amazônia (UNAMA), Santarém, PA, Brazil
}

Abstract

\begin{abstract}
The objective of this research was to evaluate the productivity of honey and pollen of Melipona interrupta (Jandaíra) colonies during a one-year period. This study was conducted in meliponiculture production colonies located in community of Coroca in the City of Santarém, Pará, from October 2016 to December 2017. All collections of meliponiculture material were conducted during the first week of each month. Characteristics such as the total number of food pots, height, diameter, and volume of honey and pollen pots, the mass of the colony, production of pollen and honey, and the productivity of the bee colony as a whole were constantly monitored. Each month, biometric measurements of fifteen colonies of native bees of the specie were conducted and analyzed in the Statistical Analysis System. The greatest honey production by these colonies was strongly correlated with the less-rainy period that occurs in the region, and this production was most pronounced during October through December.
\end{abstract}

Keywords: Brazil, bees, community, meliponiculture.

Abbreviations: LPM_honeypot width; VPM_honeypot volume; APM_honeypot height; PPM_mass of pollen; LPP_width of pollen pots; APP_height of pollen pots; NPM_number of honeypots; NPP_number of of pollen pots; VTM_total volume of honey; QTP_total quantity of pollen.

\section{Introduction}

Meliponiculture of stingless bees with honey production as a main objective has become an important agricultural activity that provides an alternative income and occupation for smallscale farmers (Venturieri et al., 2012). These bees represent a group of pollinators that provide goods and services that benefit maintenance of ecosystem services and agricultural production (Slaa et al., 2006).

Indigenous stingless bees or native ones, of the Meliponini tribe, were classified by Camargo \& Pedro (2014) and are present in all of Brazil, explained by the great biodiversity, although there are different species depending on the region studied (Lima-Verde \& Freitas, 2002), and more than 200 species of Meliponini have been described (Moure et al., 1999., Venturieri et al., 2003., Souza et al., 2009., Camargo and Pedro, 2014).

Meliponiculture products have diverse applications (CarvalhoZilse et al., 2005; Barbosa-Costa et al., 2011), as well as benefits such as aggregation of social and economic value for the rural producer through the sale, by groups formed by these producers, of products and sub-products of meliponiculture (Venturieri et al., 2003; Carvalho-Zilse and Nunes-Silva, 2012).
The characteristics that influence production by bees, as with other animals used for production of food and other products, are controlled by a large number of genes. Quantification of characteristics of economic interest in bees is difficult and requires studies conducted at the level of the colony, and involves characteristics that directly and indirectly influence productivity (Souza et al., 2002). In meliponaries, characteristics such as the total number of food pots, the height, diameter, and volume of honey and pollen pots, the mass of the colony, production of pollen and honey, and the productivity of honey and pollen of the bee colony have been investigated in the selection of the most productive colonies (Alves, 2010).

The characteristics that aggregate economic value are generally correlated among themselves and also with environmental variables inherent to the management system (Rinderer, 2008). In this manner, correlation permits the definition of the relationship between two characteristics, and enables the use of indirect selection which, in some cases, permits large genetic gains (Cruz, 2001). 
In this context, the objective of this study was to evaluate the monthly production through biometric measurements of $M$. Interrupta bee colonies in the Coroca community, Arapiuns River, Pará, Brazil.

Results

The climatic data show that rainfall is concentrated between the months of January through June, with the greatest rainfall in March and April with averages of $280 \mathrm{~mm}$ and $270 \mathrm{~mm}$, respectively (Figure 3 ); during these two months the lowest average temperatures $\left(\approx 25^{\circ} \mathrm{C}\right)$ were also recorded.

From July through December rainfall was much less frequent, and the month of October was the least rainy with an average value of less than $100 \mathrm{~mm}$. Together with this reduction in rainfall the average air temperature increased and attained an average maximum value of $28^{\circ} \mathrm{C}$. Due to the dynamic of rainfall distribution in this region the year can be divided into two periods: a rainy season (January through June), and a dry season (July through December)

During the dry season when the average air temperatures were higher there was a greater incidence of flowering by native species, and this would increase the availability of food sources for bees and consequently cause an increase in the production of honey.

The averages and standard deviations of the production parameters of colonies of $M$. interrupta (Jandaíra) for each season of the year are shown in Table 1 . The variable LPP (width of pollen pots) did not show any variation between seasons, maintaining a width of 2.4 to $2.7 \mathrm{~cm}$ throughout the year. The parameters LPM (honeypot width), VPM (honeypot volume), PMP (mass of pollen), NPM and NPP (total numbers of honeypots and pollen pots), VTM (total volume of honey), and QTP (total quantity of pollen) had greater values during the dry season (July through December), which coincides with the period of flowering of trees and plants in the region. The parameters APM and APP had greater values in the rainy season with average values of $3.87 \mathrm{~cm}$ and $4.84 \mathrm{~cm}$, respectively.These results indicate that productive parameters were significantly different between seasons $(p<0.01)$, with greater values for most parameters during the dry season when plant flowering is more intense and visits by bee species and subsequent pollination also increase. In contrast, in the rainy season, and also whenever necessary, the bees produce a casing that aids in thermoregulation and protection of the nests as shown in Fig. 4-C, while in the dry season nectar is collected and honey is produced and stored, as shown in Fig. 4$A$ and $B$.

The results show that the parameters of honey production (VTM) and pollen characteristics (QTP) had similar variation. The averages for these characteristics were greater from October through December, 2016 and then had a reduction during the following six months (January through June), and the period from April through June 2017 had the lowest average for these production parameters during the entire study period.

During the three month period from July through September, 2017 there was a recuperation of the hives wherein the number of honey pots and pollen pots increased, and consequently so did the volume of honey and the quantity of pollen produced.

These results demonstrate that the productive characteristics of honey and pollen of this species, raised in the Amazon region, are related to the variation in the quantity of rainfall between the rainy and dry seasons that is characteristic of the region.

The production of honey and pollen begins to increase when rainfall starts to decrease, reaching a maximum of production during the months of October through December. This occurs because the forest species of the region intensify the period of flowering when rainfall is reduced and air temperature is greater, which occurs in the month of July. In these conditions bees have a larger supply of food sources and they therefore increase their pollination activities, nectar collection, and storage of honey and pollen.

The averages of the height of honeypots (APM) and pollen pots (APP) were lower during the months of October through December, 2016 and 2017. During the months with more rain (January through June) and the beginning of the dry season (July through September) the pots had greater heights. These results suggest that the heights of the pots, in this species, are inversely correlated with the volume of honey and the quantity of pollen, and these results are confirmed by the negative correlations between the characteristics of APM and APP with VPM, NPM, PMP, NPP, VTM, and QTP (Table 2).

The greater height of the honey and pollen pots during the rainy season could be related to factors that contribute to thermoregulation and protection of nests (Fig. $4-\mathrm{C}$ ). The width of the honeypots (LPM) and pollen pots (LPP) did not have significant differences between seasons. The LPM varied from $2.22 \pm 0.16$ to $2.31 \pm 0.26 \mathrm{~cm}$, and the LPM varied from $2.32 \pm$ 0.11 to $2.34 \pm 0.24 \mathrm{~cm}$.

Table 2 shows the correlations for the production parameters. The VPM (honeypot volume) showed a high correlation with the other honey production parameters: NPM ( $r=0.59)$, VTM $(r=0.79)$, and pollen NPP $(r=0.52)$ and PMP $(r=0.43)$ and QTP $(r=0.55)$. For LPM $(r=0.26)$ and LPP $(r=0.20)$ the correlations were medium in strength.

These results show that honey production in the studied species is positively correlated with pollen production, meaning that during the period of greater production the bees are able to sufficiently produce honey as well as pollen and can; therefore, be managed for both of these products.

The height of the honeypots (APM) and the pollen pots (APP) were strongly and negatively correlated with the remainder of the honey production parameters (VPM, NPM, VTM), varying from -0.21 to -0.54 , and the pollen production characteristics (NPP, PMP, QTP), which varied from -0.36 to -0.55 . The widths of the honeypots (LPM) and the pollen pots (LPP) presented weak to medium-strength positive correlations with the honey production parameters $(r=0.14$ to $r=0.26)$ and the pollen production characteristics ( $r=0.05$ and $r=0.07)$, suggesting that the quantity of honey and pollen is directly related to the width of the pots. 
Table 1. Average and standard deviation (SD) of evaluated production characteristics in colonies of Melipona interrupta, in the Coroca community, Arapiuns/PA, evaluated every three semesters in the years 2016 and 2017.

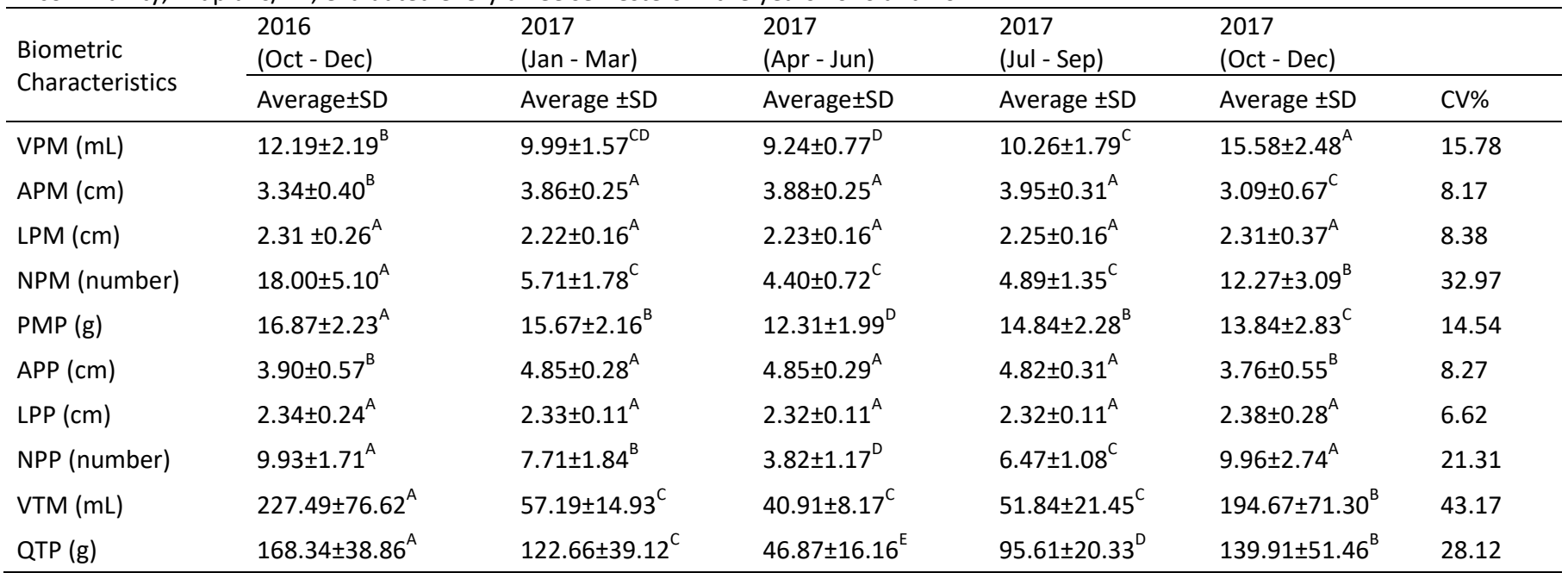

LPM: honeypot width; VPM: honeypot volume; APM: honeypot height; PPM: mass of pollen; LPP: width of pollen pots; APP: height of pollen pots; NPM: number of honeypots; NPP: number of of pollen pots; VTM: total volume of honey; QTP: total quantity of pollen. Averages followed by different letters in the same row are statistically different by the Tukey test at $1 \%$ probability. CV= coefficient of variation.
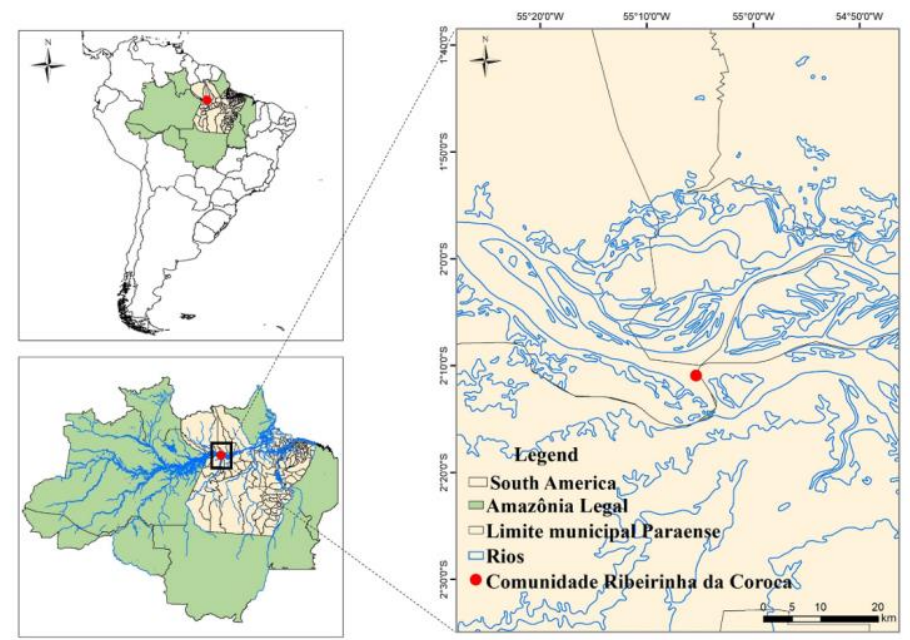

Fig 1. Map showing the location of the agroextrativist Coroca community, Arapiuns River, Pará.

Table 2. Correlation between biometric and production characteristics in colonies of Melipona interrupta, in the Coroca community, Arapiuns/PA, evaluated every three semesters in the years 2016 and 2017.

\begin{tabular}{|c|c|c|c|c|c|c|c|c|c|}
\hline & VPM & APM & LPM & LPP & APP & PMP & NPM & NPP & VTM \\
\hline VPM & - & & & & & & & & \\
\hline APM & -0.21 & - & & & & & & & \\
\hline LPM & 0.26 & 0.27 & - & & & & & & \\
\hline LPP & 0.2 & 0.05 & 0.49 & - & & & & & \\
\hline APP & -0.56 & 0.53 & -0.13 & NS & - & & & & \\
\hline PMP & 0.43 & -0.25 & 0.04 & 0.05 & -0.36 & - & & & \\
\hline NPM & 0.59 & -0.54 & 0.14 & 0.08 & -0.68 & 0.48 & - & & \\
\hline NPP & 0.52 & -0.42 & 0.1 & 0.07 & -0.53 & 0.6 & 0.68 & - & \\
\hline VTM & 0.79 & -0.48 & 0.21 & 0.13 & -0.7 & 0.47 & 0.95 & 0.68 & - \\
\hline QTP & 0.55 & -0.42 & 0.09 & 0.07 & -0.55 & 0.78 & 0.69 & 0.96 & 0.69 \\
\hline
\end{tabular}



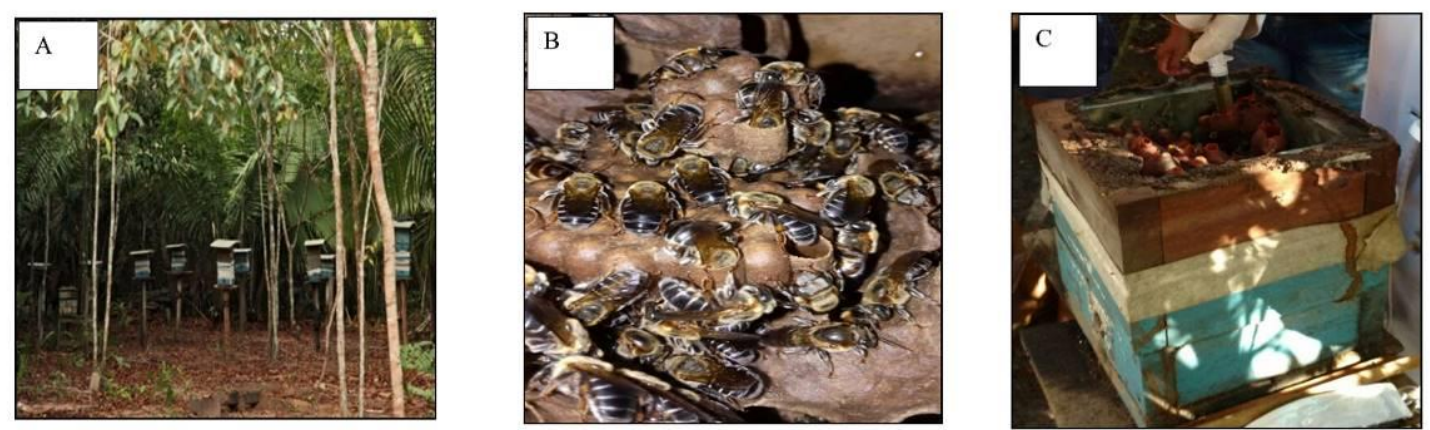

Fig 2. A- Meliponary of the Coroca community -Arapiuns River. B- M. Interrupta colony. C- Honey collection using a $20 \mathrm{~mL}$ syringe from the $M$. interrupta colony done in the months of October, 2016 and2017.

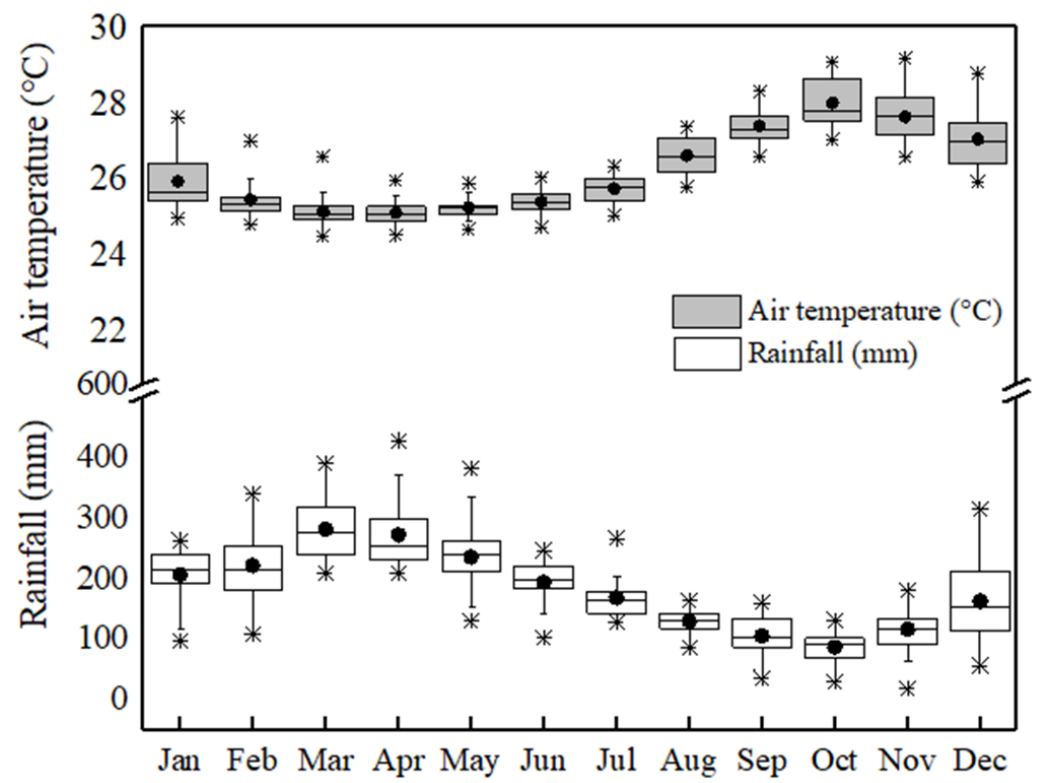

Fig 3. Monthly dynamic of average air temperature $\left({ }^{\circ} \mathrm{C}\right)$ and rainfall $(\mathrm{mm})$, from 1990 to 2010 extracted from the ECMWF climate model.
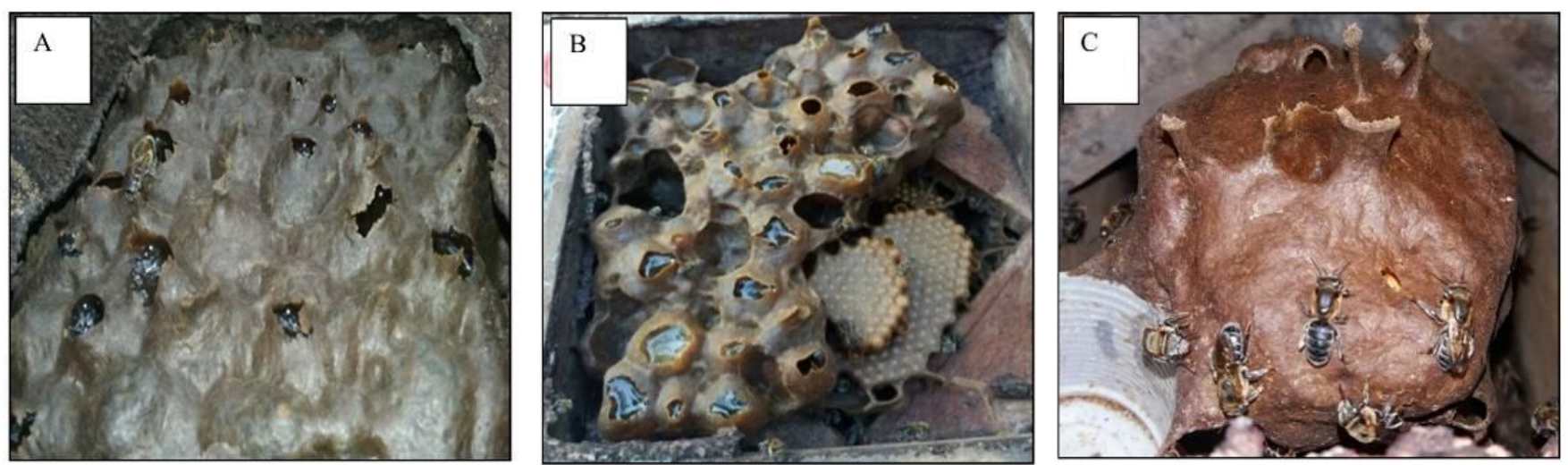

Fig 4. A- Honey production in the honeycomb with capped pots (October-December). B-Honey production in the upper nests during the last three months of this study. $\mathrm{C}-\mathrm{M}$. interrupta nest in the rainy season. 


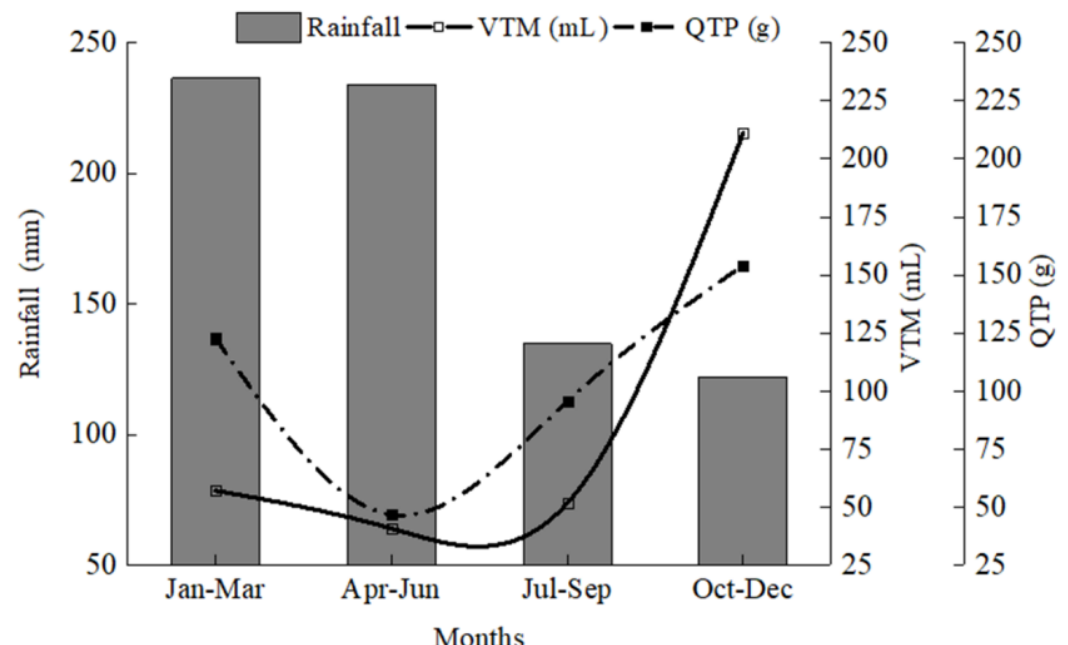

Fig 5. Production characteristics evaluated in colonies of Melipona interrupta in the rainy and dry seasons in the Coroca community, Arapiuns/PA, evaluated in three-month intervals in 2016 and 2017. VTM: total volume of honey; QTP: total quantity of pollen.

\section{Discussion}

Dias et al. (2008) studying Jandaíra (M. subtinida) bees, found an average of 55.43 for NPM (number of honeypots) in colonies that were artificially fed, and Alves (2010), studying colonies of M. scutellaris reported and average NPM of 14.96 . These values are greater than the range found in the current study for the rainy as well as the dry season (5.05 and 11.96, respectively). In light of this result it should be taken into account that each species of Meliponini constructs pots of different sizes and those external factors can have a large influence on this process (Pereira et al., 2012).

According to Alves et al. (2010), the production of honey is intrinsically linked to the number of honeypots, and consequently is related to the quantity of wax produced by worker bees, which use the honey and resin in the construction of these pots. It is important to emphasize that when LPM and APM present higher averages there is a reduction in the consumption of honey by worker bees linked to the construction of new pots.

The quantity of honey production, besides being related to the availability of flowering plants along the bee's flight radius, also needs a large number of worker (scout) bees in the field during the nectar collection period. Therefore, there is a necessity of management techniques that can supplement the growth of the colony in order to maximize the storage of honey during the harvest period (Evangelista-Rodrigues et al., 2008).

According to Oliveira et al. (2012) who studied flight activity of the species M. subtinida (Jandaíra) in the rainy season in Mossoró - RN, this species collected more nectar and water, and emphasized that changes in climate can directly influence the foraging and collection behavior of bees.

Rodrigues (2012), in an experiment using the bee species M. mandaçaia conducted in Petrolina $-P E$, related that there is an influence of climatic factors on flight activity in a hive. It was concluded that there were a greater number of worker (scout) bees engaging in flight to collect nectar during the rainy season. Alves et al. (2007) reported, for bees of the species M. mandacaia, values that are similar to those found in the current study with respect to LPP (width of pollen pots), and that these data did not demonstrate variation during the entire year of study, while Sousa et al. (2008) reported values of 2.03 $\pm 0.31 \mathrm{~cm}$, which are lower than lower those found in the current study. The quantity of honey produced had a high correlation with the availability of flowering plants along the bee's flight radius. From this result it can be inferred that there was a substantial participation of worker (scout) bees during the nectar collection period that coincided with the flowering period in the study area. This demonstrates that there exists a necessity to adopt management strategies during the period where there is less food available for the bees, such as artificial feeding to strengthen the colony in order to maximize honey production during the harvest period (Evangelista-Rodrigues et al., 2008).

It must be emphasized that supplemental information should also be considered such as bee species, model and size of nest boxes, management, environment in general, adaptability, and environmental variability (Kerr, 2006). Nevertheless, studies of correlations for different species with environmental variables and management techniques are important for increasing knowledge of production and reproduction (EvangelistaRodrigues et al., 2008) because it is through the use of biometry of production parameters that bee selection is best conducted (Fraquinello et al., 2013).

\section{Materials and Methods}

This study was conducted in meliponiculture production colonies located in the agro-extrativist settlement known as the community of Coroca, on the bank of the Arapiuns River, in the City of Santarém, Pará, with the following geographic coordinates: latitude $02^{\circ} 25^{\prime} 10.4^{\prime \prime} \mathrm{S}$ and longitude $055^{\circ} 12^{\prime} 44.2^{\prime \prime}$ W (Figure 1). 
Thirteen families live in the Coroca community, and twelve years ago they created the Association of Rural Producers of Agricultural Crops and Fish of Coroca (Aprucipesc), and the Association of Teçume Artisans (ARTA). These families also practice meliponiculture (Figure 2) and sell their produce and derivatives of native bee colonies, and also engage in agroecologiccal tourism which includes visits to the meliponaries (meliponicultourism).

The region is dominated by native forest with the following species being predominant: Taxi-branco (Sclerolobium paniculatum Vogel), Tapiririca (Tapirira guianensis Aubi., Anacardiaceae), Cumaruzeiro (Coumarounaodorata), Pequiazeiro (Caryocar brasiliense), Andirobeira (Carapa guianensis Aubl.), Breu (Protium heptaphyllum), Açai (Açaizeiro nativo (Euterpe oleracea)), Peach palm (Pupunheira (Bactris gasipaes)), Buritizeiro (Mauritia flexuosa L. f.) and others. Besides the native forest, among introduced species of trees there are Taperebazeiro, (Spondias mombin L), Orange (Citrus sinensis (L.) Osbeck), Tangerine (Citrus reticulata), Muricizeiro (Byrsonima crassifolia (L.) Rich), Mango (Mangifera indica), Guava (Psidium guajava), and Juruzeiro, among others, all of which provide important ecosystem services such as flowers that bees can visit in different periods of the year depending on the phenological phase of the diverse species present in the area.

This work was conducted from October 2016 to December 2017, and all collections of meliponiculture material were conducted during the first week of each month. Each month biometric measurements were conducted of fifteen colonies of native bees of the species Melipona interrupta (Jandaíra). The colonies belonged to a small-scale meliponiculturist and were maintained in nesting boxes of the INPA model (Vilas boas, 2012) and measured $20 \times 20 \times 8 \mathrm{~cm}$. During the period of this study the colonies were not artificially fed.

In order to conduct the biometry measurements, the boxes of the native bee colonies ( $n=15$ colonies $^{-1}$ for each of honeypots and pollen pots) were opened and the following measurements of production parameters were taken using a digital caliper: honeypot width (LPM); honeypot height APM); pollen pot width (LPP); and pollen pot height (APP). Additionally, the total numbers of honeypots (NPM), and pollen pots (NPP) were recorded, and the mass of pollen (PMP) was measured using a small spatula and was weighed on a digital balance. The honeypot volume (VPM) was measured by applying suction to the pots using $20 \mathrm{~mL}$ discardable syringes (Fig. 2 - C). The total volume of honey (VTM) for each hive was calculated by counting the pots that were capped, and then multiplying this number by the volume of the honeypots for each collection. The estimate of the total quantity of pollen (QTP) per hive was calculated by multiplying the number of capped pots by the average mass of the pollen in the pots.

Climatic data for average air temperature and monthly rainfall in the study area from 1990 to 2010 were obtained from the European Centre for Medium-Range Weather Forecasts (ECMWF) climate model. ECMWF is very accurate (Aparecido et al., 2019).

The data for biometric parameters were analyzed using the SAS (Statistical Analysis System, SAS Institute Inc., 1999) statistical software package. Analysis of variance (ANOVA) was conducted for treatment comparisons, and the Tukey test was used for subsequent mean separation at a probability level $\alpha=$ $1 \%$, and simple correlation was conducted for the production parameters (Proc. CORR, SAS, 1999).

\section{Conclusion}

The production of $M$. interrupta colonies is strongly influenced by thermal and hydrological conditions in the Coroca community, Arapiuns River, showing that greater production is strongly correlated with the dry season, especially the months of October through December, which present the greatest production of honey, and this represents a strategy for attracting honey buyers and tourists to visit this community on the Arapiuns River during this period.

\section{References}

Alves R, Souza B, Carvalho C (2007) Notas sobre a bionomia de Melipona mandacaia (APIDAE: MELIPONINA). Magistra 19: 204-212.

Alves R (2010) Avaliação de parâmetros biométricos e produtivos para seleção de colônias da Abelha Uruçu (Melipona scutellaris Latreille, 1811). Tese (Doutorado em Ciências Agrárias) - Universidade Federal do Recôncavo da Bahia, Brasil. 104f.

Alves R, Carvalho C, Faquinello P, Ledo C, Figueiredo L (2012) Parâmetros biométricos e produtivos de colônias de Melipona scutellaris Latreille, 1811 (Hymenoptera: Apidae) em diferentes gerações. Magistra 24: 105-111.

Aparecido LEO (2019) Accuracy of ECMWF ERA-Interim reanalysis and its application in the estimation of the water deficiency in Paraná, Brazil. Revista Brasileira de Meteorologia. 34(4):515-528.

Barbosa CK, Santiago J, Fraxe T (2011) Implantação da meliponicultura em comunidade rural de várzea no Amazonas. Cadernos de Agroecologia 6: 1-6.

Carvalho ZG, Silva N, Zilse N, Vilas BH, Silva C, Laray J, Freire D, Kerr W (2005) Criação de Abelhas Sem Ferrão. Brasília-DF, Edições IBAMA. 27p.

Carvalho ZG, Nunes SC (2012) Threats to the Stingless Bees in the brazilian Amazon: How to deal with scarce biological data and an increasing rate of destruction. 147-168.In: Florio, R. M. (Ed.). Bees: Biology, Threats and Colonies. Nova Science Publichers, Hauppauge, NY, USA. 327 pp.

Camargo J, Pedro S (2014) Meliponini Lepeletier, 1836. In: Moure, J. S., Urban, D. e Melo, G. A. R. (Orgs). Catalogue of Bees (Hymenoptera, Apoidea) in the Neotropical Region online version.

Cruz CD (1998) Programa GENES: Aplicativo Computacional em Estatística Aplicada à Genética (GENES - Software for Experimental Statistics in Genetics). Genetics and Molecular Biology. 21(1).

Dias V, Filgueira M, Oliveira F, Dias A, Costa E (2008) Alimentação Artificial à Base de Mel e Suas Implicações no Desenvolvimento de Famílias de Abelhas Jandaíras (Melipona subnitida Ducke) em Mossoró - RN. Revista Verde 3: $40-44$. 
Evangelista RA, Góis G, Silva C (2008) Desenvolvimento produtivo de colméias de abelhas Melipona scutellaris. Biotemas 21: 59-64.

Faquinello P, Brito B, Carvalho C, Paula LM, Alves R (2013) Correlação entre parâmetros biométricos e produtivos em colônias de Melipona quadrifasciata anthidioides Lepeletier (Hymenoptera: Apidae). Ciênc Anim Bras. 14: 312-317.

Kerr W (2006) Métodos de seleção para melhoramento genético em abelhas. Magistra. 18: 209-212.

Lima VL, Freitas B (2002) Occurrence and biogeographic aspects of Melipona quinquefasciata in NE Brazil (Hymenoptera, Apidae). Brazilian Journal Biology. 62: 479486.

Moure JS, Graf V, Urban D (1999) Catalog of the Apoidea of the neotropical region (Hymenoptera, Colletidae). I. paracolletini. Revista Brasileira de Zoologia. 16:1-46

Oliveira F, Dias V, Costa E, Filgueira M, Sobrinho J (2012) Influência das variações climáticas na atividade de voo das abelhas jandairas Melipona subnitida Ducke (Meliponinae). Revista Ciência Agronômica. 43: 598-603.

Pereira FM (2012) Manejo de colônias de abelhas-sem-ferrão. Teresina: Embrapa Meio-Norte. 31p.

Rodrigues F (2012) Aspectos do voo de Melipona mandacaia (Hymenoptera, Apidae, Meliponini) na região do Vale do Submédio São Francisco. Universidade Federal do Vale do São Francisco. Petrolina, PE.

Rinderer TE (2008) Bee genetics and breeding. Florida: Academic Press. p.305-319.
Slaa E, Chaves L, Malagodi BK, Hofstede, F (2006) Stingless bees in applied pollination: pratic and perspectives. Apidologie 37: 293-315.

Souza D, Cruz C, Campos L, Regazzi A (2002) Correlation between honey production and some morphological traits in Africanized honey bees (Apis mellifera). Ciência Rural 32: 869-872.

Souza B, Carvalho C, Alves R (2008) Notas sobre a bionomia de Melipona asilvai(Apidae: Meliponini) como subsídio a sua criação racional. Revista Archivos de Zootecnia 57: 53-62.

Souza B, Carvalho CA, Alves C, Dias C, Clarton L (2009). Munduri (Melipona asilvai): a abelha sestrosa. Série Meliponicultura. 46 p. Cruz das Almas.

Venturieri GC, Raiol V, Pereira CAB (2003) Avaliação da introdução da criação racional de Melipona fasciculata (Apidae: meliponina), entre os agricultores familiares de Bragança - PA, Brasil. Biota Neotrópica. 3: 1-7.

Venturieri GC, Alves DA, Villas BJK, Carvalho CAL, Menezes C, Vollet-Neto A, Contrera FAL, Cortopassi-Laurino $M$, Nogueira-Neto P, Imperatriz FVL (2012) Meliponicultura no Brasil: situação atual e perspectivas futuras. Polinizadores no Brasil contribuição e perspectivas para a biodiversidade, uso sustentável, conservação e serviços ambientais. São Paulo: EDUSP.

Villas BJ (2012) Manual Tecnológico: Mel de abelhas sem ferrão. Brasília: Instituto Sociedade, população e Natureza (ISPN), Brasil. 